\title{
Perbandingan Abdominal Massage dengan Teknik Swedish Massage dan Teknik Effleurage terhadap Kejadian Konstipasi pada Pasien yang Terpasang Ventilasi Mekanik di ICU
}

\author{
Arimbi Karunia Estri ${ }^{1}$, Sari Fatimah ${ }^{2}$, Ayu Prawesti ${ }^{2}$ \\ ${ }^{1}$ Akademi Keperawatan Panti Rapih Yogyakarta, ${ }^{2}$ Fakultas Keperawatan, Universitas Padjadjaran \\ Email:arimbikaruniaestri@yahoo.com
}

\begin{abstract}
Abstrak
Konstipasi merupakan komplikasi yang sering terjadi pada pasien yang dirawat di Intensive Care Unit (ICU). Teknik abdominal massage yang dapat digunakan untuk mencegah konstipasi adalah swedish massage dan effleurage, namun demikian belum ada penelitian lanjutan yang menunjukkan teknik yang paling efektif diantara kedua teknik abdominal massage tersebut terhadap kejadian konstipasi. Penelitian ini bertujuan untuk mengetahui perbedaan kejadian konstipasi antara kelompok yang dilakukan abdominal massage dengan teknik swedish massage dan kelompok yang dilakukan abdominal massage dengan teknik effleurage. Penelitian ini merupakan penelitian quasi eksperimen dengan total jumlah sampel pada dua kelompok sebanyak 22 responden yang didapatkan melalui teknik consecutive sampling. Penelitian ini dilakukan dari bulan Januari sampai Maret 2016 di ruang ICU RS Panti Rapih Yogyakarta. Data dikumpulkan melalui observasi menggunakan lembar observasi defekasi. Data dianalisis menggunakan uji Fisher's Exact. Kejadian konstipasi pada kelompok abdominal massage dengan teknik swedish massage sebanyak 45,4\%, sedangkan kejadian konstipasi pada kelompok abdominal massage dengan teknik effleurage sebanyak $27,2 \%$, dan secara statistik tidak ada perbedaan kejadian konstipasi $(p=0,659)$ antara kelompok abdominal massage dengan teknik swedish massage dan kelompok abdominal massage dengan teknik effleurage. Walaupun kejadian konstipasi antara kelompok abdominal massage dengan teknik swedish massage dan kelompok abdominal massage dengan teknik effleurage tidak berbeda, namun abdominal massage dengan teknik effleurage waktu lebih efisien, energi yang dikeluarkan lebih minimal dan meningkatkan kenyamanan. Oleh karena itu, abdominal massage dengan teknik effleurage dan teknik swedish massage disarankan untuk menjadi pilihan intervensi bagi perawat ICU.
\end{abstract}

Kata kunci: Abdominal massage, kejadian konstipasi pasien ICU, teknik effleurage, teknik swedish massage.

\section{The Comparison of Abdominal Massage, Swedish Massage and Effleurage technique towards Constipation among Patients with Mechanical Ventilation Assisted in the Intensive Care Unit}

\begin{abstract}
Abstrak
Constipation is a common problem experienced by patients hospitalised in the Intensive Care Unit (ICU). Little is known about the efficacy of abdominal massage using Swedish massage and Effleurage technique to prevent constipation. This study aimed to examine the difference of constipation occurrence between two groups administered those two massage techniques (Swedish and Euffleurage). This quasi-experimental study recruited 22 subjects obtained by using consecutive sampling technique. Data were collected using defecatiion observation form which further analysed using Fisher's Exact. Almost half of subjects administered Swedish massage have experienced constipation $(45.5 \%)$ meanwhile smaller subjects have experienced constipation administered Effleurage massage $(27.2 \%)$. Thus, there was no significant difference of constipation occurrence among these two groups $(p=0,659)$. However, Effleurage massage provided better time efficacy, minimum energy consumption, and more comforts than other technique. Nurses can use these two massages as alternatives to prevent constipation among patients in the ICU.
\end{abstract}

Keywords: Abdominal massage, constipation, effleurage technique, ICU, Swedish massage. 


\section{Pendahuluan}

Konstipasi merupakan komplikasi yang sering terjadi pada pasien yang dirawat di Intensive Care Unit (ICU), hal ini sesuai dengan beberapa penelitian yang telah dilakukan untuk melihat angka kejadian dan mendefinisikan kriteria konstipasi pada pasien kritis di ICU. Kriteria yang digunakan untuk mendefinisikan konstipasi pada pasien kritis di ICU adalah apabila tidak ada defekasi sedikitnya dalam 3-4 hari perawatan di ICU (Azedo \& Machado, 2013; Gacoin et al., 2010; Mustofa, Bhandari, Ritchie, Gratton \& Wenstone, 2003). Kejadian konstipasi paling sering terjadi pada pasien yang terpasang ventilasi mekanik. Hasil penelitian Guerra, Mendonca dan Marshall (2013) menunjukkan bahwa sebanyak $72 \%$ pasien mengalami konstipasi setelah 72 jam terpasang ventilasi mekanik.

Konstipasi disebabkan oleh penurunan motilitas gastrointestinal. Penurunan motilitas gastrointestinal terjadi karena kondisi hipoksemia, hipotensi, penggunaan ventilasi mekanik dengan positive end expiratory pressure (PEEP) dan efek samping sedasi analgetik dan vasopresor. Penelitian Gacoin et al. (2010) menunjukkan bahwa kondisi pasien dengan $\mathrm{PaO}_{2} / \mathrm{FiO}_{2}$ rasio $<150 \mathrm{mmHg}$ dan sistolic blood pressure (SBP) $<90 \mathrm{mmHg}$ selama 4 hari pemasangan ventilasi mekanik beresiko tinggi mengakibatkan konstipasi.

Penggunaan ventilasi mekanik dengan PEEP mengakibatkan peningkatan tekanan intrathoraks. Peningkatantekananintrathoraks mengakibatkan penurunan venus return yang pada akhirnya mengakibatkan penurunan curah jantung. Kondisi curah jantung yang menurun mengakibatkan tubuh melakukan mekanisme kompensasi dengan menurunkan aliran darah ke sistem gastrointestinal. Kondisi hipoperfusi ini dinamakan hipoperfusi splanchnic, hipoperfusi ini mengakibatkan iskemia mukosa gastrointestinal, penurunan sekresi bikarbonat dan penurunan motilitas gastrointestinal (Vincent \& Preiser, 2015). Hal tersebut sesuai dengan penelitian yang dilakukan oleh Aikawa et al. (2009) menunjukkan bahwa pemberian PEEP tinggi berbahaya terhadap mikrosirkulasi mesenterika.

Penggunaan obat-obatan di ICU merupakan salah satu faktor penyebab terjadinya konstipasi. Jenis obat yang paling berisiko menimbulkan konstipasi adalah jenis opioid. Penggunaan opioid meningkatkan risiko konstipasi karena efek opioid menimbulkan efek spasme otot polos gatrointestinal (Kyle, 2011). Penelitian yang dilakukan oleh Sharma, Kaur, dan Garg (2007) menunjukkan bahwa sebanyak 45,8\% pasien ICU yang mendapat terapi opioid mengalami konstipasi. Selain itu pasien ICU yang mendapatkan diet serat yang kurang dari kebutuhan beresiko untuk mengalami konstipasi (Mustafa, Bhandari, Ritchie, Gratton, dan Wenstone, 2003). Asupan serat yang cukup dapat mempertahankan kelembapan feses dengan cara menarik air secara osmosis ke dalam feces dan menstimulasi peristaltik kolon (Kyle, 2011; Corwin, 2008). Pasien dengan tirah baring juga akan berisiko mengalami konstipasi karena tidak adanya aktivitas akan memperlama waktu transit feses di kolon serta melemahkan tekanan intra abdomen (Kyle, 2011). Penelitian yang dilakukan oleh Sharma, Kaur, dan Garg (2007) menunjukan bahwa pasien ICU yang tirah baring total mengalami konstipasi sebanyak 64,1\%.

Ketidakseimbangan dalam elektrolit seperti hipokalemi, hiperkalsemi dan hipomagnesemia dapat menurunkan motilitas usus dan meningkatkan risiko konstipasi. Penurunan motilitas usus terjadi karena ketidakseimbangan elektrolit merusak kontraksi otot polos (Fruhwald, Holzer, \& Metzler, 2007). Ketidakadekuatan terapi cairan dan efek samping pemberian diuretik berisiko tinggi dehidrasi serta meningkatkan resiko terjadinya konstipasi (Vincent \& Preiser, 2015). Namun demikian, pemberian terapi cairan juga memerlukan pemantauan yang ketat karena apabila melebihi kebutuhan menyebabkan edema splanchnic yang dapat menurunkan motilitas usus (Vincent dan Preiser, 2015).

Konstipasi harus dicegah dan diatasi di ranah keperawatan kritis karena dampak yang terjadi akibat konstipasi pada pasien yang terpasang ventilasi mekanik adalah semakin lamanya penggunaan ventilasi mekanik dan semakin lamanya hari rawat pasien (Sharma, Kaur, \& Garg, 2007). Penelitian yang dilakukan oleh Mustofa, Bhandari, Ritchie, Gratton, dan Wenstone (2003) menunjukkan sebanyak 42 $\%$ pasien konstipasi mengalami gagal weaning 
ventilasi mekanik. Konstipasi menyebabkan distensi abdomen, ketidaknyamanan, dan gelisah. Distensi abdomen akan menghambat diafragma, menurunkan compliance paru, dan meningkatkan kerja pernafasan sehingga memperlama proses weaning ventilasi mekanik (Azevedo \& Machado, 2013).

Konstipasi berisiko tinggi menyebabkan intraabdominal hipertensi, sehingga kondisi tersebut berisiko menyebabkan disfungsi beberapa organ (Gacoin et al., 2010). Disfungsi organ ditunjukkan dengan peningkatan score Logistic Organ Dysfunction (LOD) dan peningkatan angka mortalitas pada pasien kritis yang tidak defekasi pada hari ke-4 sampai dengan hari ke 9 perawatan di ICU (Gacoin et al., 2010). Acquired bacterial infection secara signifikan terjadi pada pasien kritis di ICU yang mengalami konstipasi. Penemuan tersebut berdasarkan hasil penelitian yang menyebutkan bahwa terjadi peningkatan kejadian acquired bacterial infection pada pasien yang defekasi setelah hari ke 6 dirawat dibandingkan pada pasien kritis ICU yang mampu defekasi lebih awal kurang dari 6 hari perawatan di ICU (Gacoin et al., 2010).

Konstipasi yang terjadi pada pasien akan memperberat fungsi jantung terutama pada pasien kritis di ICU, karena proses defekasi disertai mengejan kuat mengakibatkan vasovagal. Vasovagal terjadi karena proses defekasi dengan mengejan yang kuat mengakibatkan kontraksi volunter otot-otot dada disertai penutupan glotis dan proses ini disebut valsava manuver. Proses valsava manuver mengakibatkan penurunan aliran darah ke jantung sehingga terjadi penurunan denyut jantung dan tekanan darah disertai dengan sesak nafas dan keringat dingin sehingga hal ini akan semakin memperberat fungsi jantung pasien kritis di ICU (Vincent \& Preiser, 2015).

Terapi farmakologi untuk mengatasi konstipasi yang sering diberikan pada pasien kritis di ICU adalah particular laxatives dan osmotic laxatives (seperti laktose). Namun demikian, konstipasi tidak selamanya berespon terhadap pemberian particular laxatives dan osmotic laxatives (seperti laktose). Efek samping dari terapi tersebut menyebabkan distensi abdomen dan ketidaknyamanan. Laktose mengakibatkan produksi gas dalam intestinal sehingga pasien merasakan kembung dan tidak nyaman di perut. Kondisi demikian turut berperan dalam menyebabkan gagalnya weaning pasien yang terpasang ventilasi mekanik (Vincent \& Preiser, 2015).

Tindakan keperawatan yang sudah dilakukan oleh perawat untuk mencegah terjadinya konstipasi adalah melakukan mobilisasi pada pasien yang tirah baring, mengelola kebutuhan cairan dan intake nutrisi dengan kandungan serat yang cukup (Vincent \& Praiser, 2015). Menurut Sharma, Kaur, \& Garg (2007) perawat ICU dalam merawat pasien harus secara komprehensif dan tidak hanya berfokus pada tindakan life saving dan rutinitas. Perawat wajib melakukan observasi defekasi pasien secara teratur minimal per shift serta mendokumentasikannya.

Terapi komplementer yang dapat dilakukan oleh perawat untuk mencegah konstipasi selain melakukan observasi defekasi adalah dengan melakukan abdominal massage. Berdasarkan beberapa hasil penelitian menunjukkan bahwa abdominal massage adalah salah satu jenis terapi komplementer yang mampu mencegah dan mengurangi gangguan pada sistem gastrointestinal (Kahraman \& Ozdemir, 2015; Tekgunduz, Gurol, Apay, \& Caner, 2014; Lamas, Lindholm, Stenlund, Engstrom, \& Jacobsson, 2010; Lai et al., 2010; Sinclair, 2011, Uysal, Eser, \& Akpinar, 2012).

Mekanisme kerja abdominal massage adalah menurunkan kontraksi dan tegangan pada otot abdomen, meningkatkan motilitas pada sistem pencernaan, meningkatkan sekresi pada sistem intestinal serta memberikan efek pada relaksasi sfingter sehingga mekanisme kerja tersebut akan mempermudah dan memperlancar pengeluaran feses (Sinclair, 2010). Review yang dilakukan oleh Sinclair (2010) menunjukkan bahwa abdominal massage telah terbukti mencegah dan mengatasi kejadian konstipasi. Penelitian yang berkaitan dengan abdominal massage telah banyak dilakukan di praktik keperawatan dan membawa manfaat serta tidak mempunyai efek samping (Sinclair, 2010; Uysal, Eser, \& Akpinar, 2012; Kahraman \& Ozdemir, 2015).

Penelitian terbaru abdominal massage di area keperawatan kritis dilakukan oleh Kahraman dan Ozdemir (2015) pada pasien yang menggunakan ventilasi mekanik yang dirawat di ICU University Hospital Turkey dan Tekgunduz, Gurol, Apay, \& Caner (2014) 
Arimbi Karunia Estri : Perbandingan Abdominal Massage dengan Teknik Swedish dan Effleurage

pada bayi prematur yang dirawat di Neonatal Intensive Care Unit (NICU) University Hospital Turkey. Hasil penelitian Kahraman \& Ozdemir (2015) dan Tekgunduz, Gurol, Apay, \& Caner (2014) menunjukkan bahwa tindakan abdominal massage terbukti efektif mengurangi gastric residual volume (GRV) dan menurunkan distensi abdomen.

Pelaksanaan abdominal massage di area keperawatan kritis untuk mencegah konstipasi pada pasien yang terpasang ventilasi mekanik masih belum dilakukan, hal ini berdasarkan penelusuran peneliti terhadap hasil penelitian yang terpublikasi online. Pelaksanaan abdominal massage sangat mungkin untuk diterapkan di area keperawatan kritis karena abdominal massage tidak ada efek samping dan telah terbukti bermanfaat mencegah konstipasi sesuai dari hasil penelitian Lamas et al. (2010) dan Lai et al., (2010). Namun demikian masih terdapat perbedaan teknik dalam pelaksanaan abdominal massage (Sinclair, 2010).

Teknik abdominal massage yang sering digunakan adalah teknik swedish massage. Teknik swedish massage selama 15 menit terbukti efektif dalam pelaksanaan abdominal massage serta bermanfaat dalam mengatasi gangguan sistem gastrointestinal (Sinclair, 2010). Teknik swedish massage telah digunakan oleh Lai et al. (2010) dalam pelaksanaan abdominal massage pada pasien kanker yang dirawat di Princess Margareth Hospital Hong Kong China dan terbukti efektif mengatasi konstipasi. Teknik Swedihs massage juga telah digunakan oleh Uysal, Eser, \& Akpinar (2012) pada pasien di unit saraf dan bedah saraf University Hospital Turkey yang mendapatkan nutrisi enteral secara intermiten.

Teknik swedish massage juga telah digunakan oleh Kahraman \& Ozdemir (2015) pada pada pasien yang menggunakan ventilasi mekanik yang dirawat di ICU University Hospital Turkey. Teknik swedish massage yang digunakan oleh Uysal, Eser, \& Akpinar, (2012) dan Kahraman \& Ozdemir (2015) juga terbukti efektif mencegah peningkatan gastric residual volume (GRV), distensi abdomen dan vomitus.

Teknik yang berbeda dilakukan oleh Lamas et al. (2010) yang menggunakan teknik effleurage selama 7 menit, dilakukan satu kali sehari selama 5 hari pada pasien yang mengalami konstipasi dan distensi abdomen di Swedia. Hasil penelitian menunjukkan bahwa abdominal massage dengan teknik effleurage selama 7 menit terbukti efektif mengatasi konstipasi dan distensi abdomen. Mengingat beban kerja perawat ICU yang tinggi namun dituntut untuk melakukan perawatan secara holistik dan mengatasi kegawatdaruratan dengan cepat dan tepat tentunya pelaksanaan abdominal massage selama 7 menit mungkin untuk dilakukan.

Perbedaan teknik abdominal massage antara teknik Swedish massage dan teknik effleurage terletak pada lamanya waktu yang dibutuhkan dan gerakan massage yang dilakukan. Kedua teknik abdominal massage tersebut mempunyai manfaat yang sama untuk mencegah konstipasi, namun belum ada penelitian lanjutan yang menunjukkan teknik abdominal massage yang lebih efektif menurunkan kejadian konstipasi dan berdasarkan penelusuran publikasi online, penelitian yang peneliti lakukan belum pernah dilakukan di area keperawatan kritis. Berdasarkan hal tersebut maka peneliti akan melakukan penelitian dengan membandingkan intervensi abdominal massage teknik swedish massage dan abdominal massage teknik effleurage di area keperawatan kritis pada pasien yang terpasang ventilasi mekanik dalam upaya pencegahan konstipasi. Teknik effleurage yang peneliti lakukan berdasarkan penelitian Lamas et al. (2009) yang melakukan abdominal massage dengan teknik effleurage selama 7 menit. Teknik swedish massage yang peneliti lakukan berdasarkan penelitian Uysal, Eser, dan Akpinar (2012), Lai et al. (2010) dan Kahraman dan Ozdemir (2015) yang melakukan abdominal massage dengan teknik swedish massage selama 15 menit. Peneliti akan melakukan penelitian di ICU RS Panti Rapih Yogyakarta karena berdasakan studi pendahuluan yang dilakukan oleh peneliti menemukan fenomena bahwa konstipasi terjadi pada pasien yang terpasang ventilasi mekanik setelah 3-4 hari perawatan di ICU, dan belum adanya penerapan tindakan komplementer untuk pencegahan kejadian konstipasi. 
Arimbi Karunia Estri : Perbandingan Abdominal Massage dengan Teknik Swedish dan Effleurage

\section{Metode Penelitian}

Penelitian ini dirancang dengan menggunakan pendekatan metode quasi eksperimental post test only non equivalent control group. Pada penelitian ini mengidentifikasi perbedaan kejadian konstipasi antara kelompok yang dilakukan abdominal massage dengan teknik swedish massage dibandingkan kelompok yang dilakukan abdominal massage dengan teknik effleurage pada pasien yang dirawat di ICU RS Panti Rapih Yogyakarta. Variabel bebas dalam penelitian ini yaitu intervensi abdominal massage dengan teknik swedish massage dan teknik effleurage, serta variabel terikatnya adalah kejadian konstipasi yang ditunjukkan dengan defekasi $>3$ hari.

Populasi pada penelitian ini adalah semua pasien yang menggunakan ventilasi mekanik yang dirawat di ICU RS Panti Rapih Yogyakarta. Pengambilan sampel pada penelitian ini diambil dengan menggunakan teknik non probabilty sampling dengan metode consecutive sampling (Dahlan, 2013). Kriteria inklusi adalah usia $>18$ tahun, hemodinamik stabil ditunjukkan dengan tekanan darah sistol 90-140 $\mathrm{mmHg}$ dan diastole $60-90 \mathrm{mmHg}$, heart rate (HR) 60-100 kali/menit, $\mathrm{PaO}_{2}>$ $150 \mathrm{mmHg}$, Saturasi $\mathrm{O}_{2}>95 \%$, pasien dengan bising usus normal (5-30 X/menit), pasien yang baru dirawat dan belum mengalami konstipasi, dan pola buang air besar rutin minimal 2 hari sekali dengan konsistensi feces lunak. Sedangkan kriteria eksklusinya adalah pasien yang mendapat muscle relaxant, pasien yang mengalami gangguan integritas kulit di abdomen, pasien post bedah abdomen, pasien mengalami perdarahan intestinal, pasien dengan luka bakar di abdomen, pasien yang mendapatkan terapi laksatif/ enema, pasien dengan tekanan tinggi intrakranial seperti stroke pada 24 jam pertama, dan trauma kepala. Total jumlah sampel yaitu 22 responden yang terbagi dalam 2 kelompok yaitu kelompok abdominal massage dengan teknik swedish massage dan kelompok abdominal massage dengan teknik effleurage.

Teknik pengumpulan data yang digunakan untuk mendapatkan data pada penelitian ini adalah menggunakan lembar observasi defekasi yang terdiri dari frekuensi defekasi. Observasi dilakukan pada hari ke 4 setelah dilakukan abdominal massage. Abdominal massage dengan teknik swedish massage maupun dengan teknik effleurage dilakukan sebanyak 2 kali sehari selama 3 hari.

Analisis data yang digunakan adalah analisa univariat dan analisa bivariat. Analisis univariat untuk menjelaskan karakteristik responden meliputi umur, karakteristik responden berdasarkan faktor yang memengaruhi konstipasi meliputi status cairan, status kecukupan kebutuhan nutrisi, status mobilisasi, dan status sedasi. Analisis bivariat menggunakan uji Fisher's exact untuk menjelaskan perbedaan kejadian konstipasi kelompok I dan kelompok II. Penelitian ini dilaksanakan di ICU RS Panti Rapih Yogyakarta mulai bulan Januari 2016 sampai dengan Maret 2016.

\section{Hasil Penelitian}

Karakteristik Intervensi Swedish Massage Intervensi Effleurage

Tabel 1 Distribusi Frekuensi Kejadian Konstipasi berdasarkan Karakteristik Responden pada Kelompok Abdominal Massage dengan Teknik Swedish Massage dan Teknik Effleurage

\begin{tabular}{lcccc}
\hline \multirow{2}{*}{ Karakteristik } & \multicolumn{2}{c}{ Intervensi Swedish Massage } & \multicolumn{2}{c}{ Intervensi Effleurage } \\
\cline { 2 - 5 } & Konstipasi & Tidak Konstipasi & Konstipasi & Tidak Konstipasi \\
\hline Usia (Tahun) & 0 & 1 & 0 & 0 \\
$18-20$ tahun & 0 & 0 & 1 & 2 \\
$21-40$ tahun & 4 & 4 & 2 & 1 \\
$41-60$ tahun & 1 & 1 & 0 & 5 \\
60 tahun & & & \\
\hline
\end{tabular}


Arimbi Karunia Estri : Perbandingan Abdominal Massage dengan Teknik Swedish dan Effleurage

\begin{tabular}{lcccc}
\hline \multirow{2}{*}{ Karakteristik } & \multicolumn{2}{c}{ Intervensi Swedish Massage } & \multicolumn{2}{c}{ Intervensi Effleurage } \\
\cline { 2 - 5 } & Konstipasi & Tidak Konstipasi & Konstipasi & Tidak Konstipasi \\
\hline Kecukupan Nutrisi & 1 & 5 & 2 & 7 \\
Cukup & 4 & 1 & 1 & 1 \\
Kurang & 1 & & & \\
Balance Cairan & 4 & 5 & 1 & 7 \\
Balance positif & 1 & 1 & 2 & 1 \\
Balance negatif & 3 & 5 & 1 & 6 \\
Status Sedasi & 1 & 1 & 1 & 2 \\
Sedasi ringan & & 0 & 1 & 0 \\
Sedasi sedang & 1 & & & \\
Sedasi berat & & & & \\
\hline
\end{tabular}

Tabel 2 Perbedaan Kejadian Konstipasi antara Kelompok Abdominal Massage dengan Teknik Swedish Massage dan Kelompok Abdominal Massage dengan Teknik Effleurage

\begin{tabular}{lccc}
\hline & Konstipasi & Tidak Konstipasi & Exact Sig. (2-sided) \\
\hline Swedish & 5 & 6 & 0,659 \\
Effleurage & 3 & 8 & \\
Total & 8 & 14 & \\
\hline
\end{tabular}

Kejadian konstipasi berdasarkan karakteristik responden yang ditunjukkan pada tabel 1 terlihat bahwa responden yang mengalami konstipasi sebanyak 6 responden berada pada rentang usia 41-60 tahun (dewasa madya). Konstipasi lebih banyak terjadi pada responden dengan belum terpenuhinya nutrisi sebanyak 5 responden dan lebih banyak terjadi pada responden dengan balance cairan negatif yaitu sebanyak 6 responden. Konstipasi lebih banyak terjadi responden dengan status sedasi sedang.

Berdasarkan tabel 2 diperoleh data bahwa kejadian konstipasi pada kelompok abdominal massage dengan teknik swedish massage sebanyak 5 responden dan kejadian konstipasi pada kelompok abdominal massage dengan teknik effleuarage sebanyak 3 responden. Berdasarkan Uji Fisher's Exact didapatkan nilai Exact Sig. (2-sided) adalah 0,659 . Hal ini menunjukkan bahwa nilai nilai Exact Sig. (2-sided) $>0,05$, maka $\mathrm{H}_{0}$ diterima yang berarti tidak terdapat perbedaan kejadian konstipasi antara kelompok yang dilakukan abdominal massage dengan teknik swedish massage dan kelompok abdominal massage dengan teknik effleurage.

\section{Pembahasan}

Hasil penelitian yang ditunjukkan pada tabel 2 didapatkan hasil bahwa tidak terdapat perbedaan kejadian konstipasi pada kelompok yang dilakukan abdominal massage dengan teknik swedish maupun pada kelompok abdominal massage dengan teknik effleurage. Hasil penelitian ini menunjukkan bahwa abdominal massage dengan teknik swedish massage dan abdominal massage dengan teknik effleurage dapat menjadi pilihan untuk digunakan dalam pelaksanaan abdominal massage di ICU karena tidak terdapat perbedaan kejadian konstipasi. Pelaksanaan abdominal massage dengan teknik swedish massage maupun dengan teknik effleurage dapat meningkatkan dan merangsang peristalktik usus. Hal tersebut sangat membantu karena pada pasien yang terpasang ventilasi mekanik beresiko terjadi penurunan peristaltik usus dan hipoperfusi splanchnic karena kondisi tirah baring, pengaruh sedasi, dan penggunaan PEEP (McClurg \& Strong, 2011).

Hasil penelitian ini mendukung hasil penelitian sebelumnya yang dilakukan oleh Lamas et al. (2010) dengan teknik effleurage 
dan Lai et al. (2010), McClurg, Hagen, Hawkins, dan Strong (2011) dengan teknik swedish massage mampu mengurangi kejadian konstipasi dibandingkan pasien yang tidak dilakukan tindakan abdominal massage. Pasien yang mengalami konstipasi akan mengalami beberapa keluhan, seperti ketidaknyamanan dan distensi abdomen yang berkontribusi dalam meningkatkan lamanya waktu penggunaan ventilasi mekanik. Pencegahan konstipasi tidak hanya perlu dilakukan di tatanan keperawatan kritis, namun juga perlu untuk dicegah di tatanan keperawatan komunitas (Rogers, 2013). Mekanisme kerja abdominal massage menstimulasi sistem saraf parasimpatis sehingga menurunkan tegangan pada otot abdomen, meningkatkan motilitas sistem gastrointestinal, meningkatkan sekresi sistem gastrointestinal dan merelaksasikan sfingter sehingga melalui mekanisme kerja tersebut akan mempermudah dan memperlancar pengeluaran feses (Sinclair, 2010).

Hasil pengolahan data penelitian ini secara statistik memang tidak menunjukkan adanya perbedaan kejadian konstipasi, namun bila dilihat pada tabel 2 kejadian konstipasi pada kelompok abdominal massage dengan teknik swedish massage lebih besar yaitu sebanyak 5 responden dari 11 responden dibandingkan pada kelompok abdominal massage dengan teknik effleurage yaitu sebanyak 3 responden dari 11 responden. Analisa berdasarkan waktu pelaksanaan abdominal massage, teknik effleurage lebih singkat yaitu membutuhkan waktu 7 menit sedangkan untuk intervensi swedish massage membutuhkan waktu 15 menit. Jumlah energi yang dikeluarkan oleh perawat tentunya akan lebih sedikit pada saat melakukan abdominal massage dengan teknik effleurage dibandingkan dengan pelaksanaan abdominal massage teknik swedish massage.

Efisiensi waktu melakukan tindakan komplementer seperti abdominal massage perlu untuk dilakukan mengingat beban kerja perawat ICU yang tinggi, sedangkan dituntut untuk melakukan perawatan secara holistik serta mengatasi kegawatdaruratan dengan cepat dan tepat. Hal tersebut sesuai dengan yang diungkapkan oleh Lindquist, Tracy, Savik, \& Watanuki (2013) yang menyebutkan bahwa pelaksanaan terapi komplementer di ICU perlu memperhatikan beberapa hal diantaranya kriteria pasien yang tepat untuk dilakukan terapi komplementer, manfaat, biaya, efektif dan efisien waktu yang dibutuhkan untuk melakukan terapi komplementer. Lindquist, Tracy, Savik, \& Watanuki (2013) merekomendasikan kepada perawat ICU meningkatkan penerapan evidence base sebagai terapi komplementer melalui penelitian untuk membuktikan manfaat dari terapi komplementer tersebut bagi pasien ICU.

Analisis respon responden setelah dilakukan abdominal massage dikaji dengan cara menanyakan respon responden terhadap kenyamanan pada saat dilakukan abdominal massage. Tiga responden intervensi effleurage mengangguk yang menunjukkan nyaman dan terlihat raut wajah tampak rileks serta tidak terjadi peningkatan heart rate (HR) dan tidak terjadipeningkatantekanandarahdibandingkan dengan sebelum dilakukan abdominal massage. Sedangkan dua responden lainnya pada kelompok intervensi swedish massage menggelengkan kepala yang menunjukkan tidak nyaman dan terlihat raut wajah tampak meringis menahan sakit pada saat dilakukan kneading dan vibrasi yang merupakan bagian dari teknik swedish massage. Hal tersebut kemungkinan karena penekanan massage yang terlalu dalam, serta teknik kneading yang melakukan gerakan memutar menggunakan jari tangan dan teknik vibrasi yang melakukan gerakan menggetarkan area perut (Goldstein \& Casanelia, 2009).

Faktor kenyamanan yang dirasakan responden kelompok intervensi effleurage sesuai dengan hasil penelitian yang dilakukan oleh Lamas, Graneheim, dan Jacobsson (2011) yang menunjukkan bahwa responden merasakan nyaman pada saat dilakukan massage maupun setelah dilakukan massage serta pada saat defekasi. Intervensi dengan teknik effleurage dapat meningkatkan kenyamanan karena gerakan effleurage merupakan gerakan massage yang sistematis yaitu mulai dari kolon asenden-tranversumdesenden sehingga gerakan yang sistematis ini meningkatkan aliran darah lokal di sekitar area yang dipijat serta semakin meningkatkan sekresi endorpin sehingga responden akan merasakan rileks dan nyaman (Hajbaghery, Abasi, \& Behestabad, 2013; Supa'at, Zakaria, Maskon, Aminuddin, \& Nordin, 2013; 
Goldstein \& Casanelia, 2009).

Keluhan kurang nyaman pada kelompok intervensi swedish massage turut berkontribusi dalam memengaruhi defekasi responden, terbukti bahwa responden yang mengeluh kurang nyaman tersebut termasuk dalam responden kelompok swedish massage yang mengalami konstipasi. Hasil temuan peneliti mengenai keluhan kurang nyaman pada kelompok swedish massage sesuai dengan hasil penelitian yang dilakukan oleh Wiest, Asphaug, Carr, Gowen, \& Hartnett (2015) yang menunjukkan bahwa teknik swedish massage mempunyai pengaruh yang rendah dalam menurunkan keluhan nyeri pada responden dengan nyeri kronis. Wiest, Asphaug, Carr, Gowen, \& Hartnett (2015) merekomendasikan pada penelitian selanjutnya untuk melakukan kombinasi swedish massage. Namun demikian pengkajian kenyamanan yang dirasakan oleh responden tidak semuanya dilakukan karena kondisi responden dalam pengaruh sedasi dan penurunan kesadaran. Meskipun menurut Grap et al. (2012) menunujukkan bahwa level sedasi tidak memengaruhi kenyamanan pasien. Oleh karena itu perlu adanya penggunaan alat ukur yang tepat untuk mengukur tingkat kenyamanan responden setelah dilakukan abdominal massage.

Kenyamanan yang dirasakan responden mampu menurunkan tingkat kecemasan responden dan memaksimalkan efek massage, hal ini telah dibuktikan oleh Hajbaghery, Beheshtabed, \&Abasi (2013) pada pasien acute coronary syndrome dan chronic myocardial infarction. Hasil penelitian Hajbaghery, Beheshtabed, \&Abasi (2013) menunjukkan bahwa setelah dilakukan whole body massage responden mengatakan nyaman dan cemas berkurang serta didukung data objektif yaitu adanya penurunan level kortisol pada sampel darah responden intervensi dibandingkan responden kontrol.

Efek yang ditimbulkan dari abdominal massage selain mencegah konstipasi dan memberikan kenyamanan juga dapat memengaruhi hemodinamik ditunjukkan dengan penurunan $\mathrm{HR}$, dan tekanan darah setelah dilakukan abdominal massage dengan teknik swedish massage dan teknik effleurage. Rata-rata penurunan HR adalah 5 kali/ menit, penurunan sistolik $10 \mathrm{mmHg}$, dan penurunan diastolik $5 \mathrm{mmHg}$. Temuan tersebut sesuai dengan penelitian Supa'at, Zakaria, Maskon, Aminuddin, \& Nordin (2013) menyebutkan bahwa setelah dilakukan massage rata-rata akan terjadi penurunan sistolik $12 \mathrm{mmHg}$ dan diastolik $5 \mathrm{mmHg}$ dan penurunan signifikan dari heart rate.

Penurunan HR dan tekanan darah dapat terjadi karena efek dari massage mengakibatkan perubahan tekanan gradien antara jaringan dan pembuluh darah sehingga memungkinkan pergerakan cairan antara jaringan ke pembuluh darah serta sebaliknya (Hajbaghery, Abasi, \& Beheshtabed, 2014). Selain itu mekanisme kerja dari abdominal massage khususnya pada teknik swedish massage adalah adanya perangsangan pada saraf parasimpatik sehingga mampu menurunkan heart rate, frekuensi pernafasan, dan tekanan darah ke rentang normal.

Responden yang berhasil defekasi setelah dilakukan abdominal massage dengan teknik swedish massage maupun teknik effleurage terus mengalami defekasi pada hari ke-4 sampai dengan hari ke-6. Namun demikian peneliti tidak mengobservasi secara penuh tentang lamanya pasien akan terus mengalami defekasi meskipun tidak dilakukan lagi abdominal massage. Efek abdominal massage meskipun intervensi sudah dihentikan pernah dilaporkan oleh Lamas et al. (2009) dan Kim et al. (2005) yang menunjukkan bahwa efek abdominal massage dapat berlangsung selama 7-10 hari setelah dilakukan abdominal massage. Namun demikian, pada penelitian ini peneliti tidak mengobservasi lebih lanjut lamanya waktu efek abdominal massage terhadap defekasi meskipun tidak lagi dilakukan abdominal massage.

Kejadian konstipasi berdasarkan pada tabel 2 lebih banyak terjadi pada kelompok abdominal massage dengan teknik swedish massage dibandingkan kelompok abdominal massage dengan teknik effleurage. Hal ini terjadi karena pada kelompok swedish massage, sebagian pasien memiliki karakteristik balance cairan negatif per 24 jam, intake nutrisi tidak mencukupi kebutuhan, mendapatkan sedasi midazolam dosis $0,1 \mathrm{mg} /$ $\mathrm{Kg} \mathrm{BB}$ dengan status sedasi sedang. Balance cairan negatif berisiko meningkatkan kejadian konstipasi karena ketidakseimbangan cairan mengakibatkan penurunan volum intravaskular dan penurunan tekanan darah 
yang memicu pelepasan katekolamin dan vasoaktif peptida lainnya. Kondisi demikian mengakibatkan penurunan aliran darah splanchnic dan penurunan suplai oksigen splanchnic sehingga bowel mengalami iskemia dan terjadi penurunan motilitas usus yang berkontribusi terhadap terjadinya konstipasi (Btaiche, Chan, Pleva, \& Kraft, 2010). Namun demikian status cairan pada pasien kritis di ICU akan lebih baik didapatkan dari nilai central venous pressure (CVP), namun pada penelitian ini nilai CVP tidak dapat diukur karena tidak semua responden terpasang CVP.

Penyebab tidak terpenuhinya intake nutrisi enteral pada 4 responden dari 11 responden pada kelompok swedish massage kemungkinan penurunan disebabkan motilitas gaster yang mengakibatkan lambatnya pengosongan lambung yang di tunjukkan dengan meningkatnya gastric residual volume (GRV). Peningkatan GRV selain karena penurunan motilitas gaster juga dipengaruhi oleh cara pemberian nutrisi enteral. Pada penelitian ini, pemberian nutrisi enteral diberikan melaui cara gravity drip. Menurut Munawaroh, Handoyo, \& Astutiningrum (2012) bahwa kejadian peningkatan GRV lebih banyak terjadi pada pemberian nutrisi melalui gravity drip dibandingkan dengan pemberian intermitten feeding karena pemberian nutrisi enteral secara bertahap akan memaksimalkan pengosongan lambung.

Pada responden penelitian ini penyebab lain penurunan motilitas gastrointestinal yang dapat meningkatnya risiko konstipasi adalah pemberian sedasi midazolam. Peneliti melakukan pemantauan status sedasi pada hari pertama pemberian sedasi dan pemantauan sedasi pada hari ke empat pada saat dilakukan obeservasi frekuensi defekasi pasien. Pemantauan sedasi dilakukan dengan menggunakan Richmond Agitatition Sedation Scale (RASS), hasil menunjukkan bahwa sebagian besar responden yang mengalami konstipasi berada pada status sedasi sedang dan berat. Pemberian terapi midazolam menghambat pengosongan lambung serta memperlama waktu transit pada sistem gastrointestinal, sehingga hal ini meningkatkan resiko konstipasi (Nguyen et al., 2008). Sebagian besar responden yang mengalami konstipasi pada penelitian ini berada pada rentang umur 41-60 tahun karena sebanyak 68,2\% dari jumlah responden berada pada rentang umur 41-60 tahun. Bertambahnya umur bukan merupakan penyebab utama terjadinya konstipasi. Namun beberapa kondisi tubuh yang terjadi seiring dengan bertambahnya umur seperti penyakit sistemik yang terjadi, penggunaan obat-obatan yang mempunyai efek konstipasi, perubahan pola diet merupakan penyebab terjadinya konstipasi (Rani, Simadibrata, \& Syam, 2011). Penelitian ini memiliki keterbatasan yaitu tidak menghitung lamanya efek abdominal massage terhadap defekasi pada saat abdominal massage sudah dihentikan dan tidak mengukur respon responden terhadap kenyamanan pada saat dilakukan abdominal massage.

\section{Simpulan}

Hasil penelitian ini menyimpulkan bahwa tidak ada perbedaan kejadian konstipasi pada kelompok abdominal massage dengan teknik swedish massage maupun pada kelompok abdominal massage dengan teknik effleurage, meskipun teknik effleurage lebih efisien dalam waktu pelaksanaan, energi yang dikeluarkan lebih minimal, gerakan massage lebih sistematis dan mudah untuk diterapkan, serta memberikan efek kenyamanan. Abdominal massage dengan teknik effleurage dan swedish massage dapat menjadi pilihan intervensi untuk pencegahan konstipasi pada pasien yang terpasang ventilasi mekanik.

Hasil penelitian ini dapat dijadikan sebagai salah satu terapi komplementer yang dapat dikembangkan di tatanan keperawatan kritis serta dijadikan dasar penelitian lanjutan mengenai lamanya efek abdominal massage terhadap defekasi meskipun abdominal massage sudah dihentikan. Saran bagi para praktisi keperawatan direkomendasikan untuk menggunakan abdominal massage dengan teknik effleurage dan swedish massage. Saran bagi penelitian selanjutnya yaitu penelitian ini dapat dijadikan dasar bagi penelitian lanjutan terkait pengaruh abdominal massage dengan teknik effleurage terhadap kenyamanan dan efek abdominal massage terhadap defekasi pada saat abdominal massage sudah dihentikan. 
Arimbi Karunia Estri : Perbandingan Abdominal Massage dengan Teknik Swedish dan Effleurage

\section{Daftar Pustaka}

Aikawa, P., Farsky, S.H., Oliveira, M.A., Pazetti, R., Mauad, T., Sannomiya, P., \& Nakagawa, N.K. (2009). Effect of different peep levels on mesenteric leukocyte endothelial interactions in rats during mechanical ventilation. Clinics (Sao Paulo), 64(5), 443-50.

Azevedo, R.P., \& Machado, F.R. (2013). Constipation in critically ill patients:much more than we imagine. Rev Bras Ter Intensiva, 25(2), 73-78.

Btaiche, I., Chan, L.N., Pleva, M., \& Kraft, M.D. (2010). Critical illness, gastrointestinal complications, and medication therapy during enteral feeding in critically ill adult patients. Nutrition in Clinical Practice, 25(1), 33-49.

Corwin, E.J. (2008). Handbooks of pathophysiology (3rd Ed.). Lippincott Williams \& Wilkins.

Dahlan, M.S. (2013). Besar sampel dan cara pengambilan sampel: dalam penelitian kedokteran dan kesehatan (Edisi 2). Jakarta: Salemba Medika.

Fruhwald, S., Holzer, P., \& Metzler, H. (2007). Intestinal motility disturbances in intensive care patients pathogenesis and clinical impact. Intensive Care Med, 33, 36-44.

Gacoin, A., Camus, C., Gros A, Isslame, S., Lavoue, S., Chimot, L., Donnio, P.Y., \& Le Tulzo, Y. (2010). In long term ventilated patients: associated factors and impact on intensive care unit outcomes. Crit care med, 38(10), 1933-8.

Goldstein, S., \& Casanelia, L. (2009). The Techniques Of Swedish Massage.Diperoleh tanggal 2 April 2016, dari www. Elsevierhealth. com.

Grab, M.J., Munro, C., Wetzel, P.A., Ketchurn, J., Hamilton, A., Artef, N., Pickler, R., \& Sessler, C. (2012). Sedation in adults receiving mechanical ventilation: physiological and comfort outcomes. American Journal of Critical Care, 21(3), 53-63
Guerra, T.L., Mendonca, S.S., \& Marshall, N.G. (2013). Incidence of constipation in an intensive care unit. Rev Bras Ter Intensiva, 25(2), 87-92.

Hajbaghery, M.A., Beheshtabad, R., \& Abasi, A. (2013). Effect of whole body massage by patient's companion on the level of blood cortisol in coronary patients: a randomized controlled trial. Nursing and Midwifery Studies, 2(3), 11-15.

Hajbaghery, M.A., Abasi, A., \& Beheshtabad, R. (2014). Whole body massage for reducing anxiety and stabilizing vital signs of patients in cardiac care unit. Medical Journal Of The Islamic Republic Of Iran (MJIRI), 28(47), 2-9.

Kahraman, B.B., \& Ozdemir, L. (2015). The Impact of abdominal massage adminestered to intubated and enterall fed patients on the development of ventilasi mekanik associated pneumonia: a randomized controlled study. International Journal of Nursing Studies, 519524.

Kim et al. (2005). Effect of aromatherapy massage for the relief constipations in the elderly. Taehan Kanho Hakhue Chi. 35(1), $56-64$.

Kyle.G. (2011). Constipation: review of management and treatment. Journal of Community Nursing, 23(6), 30-38.

Lai, T.K.T., Cheung, M.C., Lo, C.K., Ng, K.L., Fung, Y.H., Tong, M., \& Yau, C.C. (2010). Effectiveness of aroma massage on advanced cancer patients with constipations: Apilot study. Elsevier, 1-7.

Lamas, K., Lindholm, L., Stenlund, H., Engstrom, B., \& Jacobsson, C. (2010). Efects of abdominal massage in management of constipations. International Journal of Nursing Studies, 46(6), 759-767.

Lamas, K., Graneheim, U.H., \& Jacobsson, C. (2011). Experience of abdominal massage for constipation. Journal of Clinical Nursing, 21, 757-765. 
Arimbi Karunia Estri : Perbandingan Abdominal Massage dengan Teknik Swedish dan Effleurage

Lindquist, R.., Tracy, M.F., Savik, K., \& Watanuki, S. (2013). Regional use of complemnetary and alternative therapies by critical care nurses. American Association of Critical Care Nurses, 12, 63-75

McClurg, D., \& Strong, A.L. (2011). Does abdominal massage relieve constipation?. Nursing Times, 107(12), 20-22.

McClurg, D., Hagen, S., Hawkins, S., \& Strong, A.L. (2011). Abdominal massage for the allevation og constipation symptoms in people with multiple sclerosis : a randomized controlled feasibility study. Multiple Sceloris Journal, 7(2), 223-233.

Munawaroh, S.W., Handoyo., \& Astutiningrum, D. (2012). Efektifitas pemberian nutrisi enteral terhadap metode intermitten feeding dan gravity drip terhadap volume residu lambung pada pasien kritis di ruang ICU RSUD Kebumen. Jurnal Ilmiah Kesehatan Keperawatan, 8(3), 141-152.

Mustofa, S.M., Bhandari, S., Ritchie, G., Gratton, N., \& Wenstone, R. (2003). Constipation and its implications in the critically ill patients. British Journal of Anaesthesia, 91(6), 815-819.

Kim et al. (2005). Effect of aromatherapy massage for the relief constipations in the elderly. Taehan Kanho Hakhue Chi. 35(1), 56-64.

Nguyen, M.N., Chapman, M.J., Fraser, R.J., Bryant, L.K., Burgastad, C., Ching, K., Bellon, M.S., \& Holloway, R.H. (2008). The effect of sedation on gastric empyting and intragastric meal distribution in critical illnes. Intensive Care MedI, 34(3), 454-460.

Rani, A., Simadibrata, M., \& Syam, A.F. (2011). Buku ajar gastroenterologi (Edisi 1).
Jakarta: Internal Publishing.

Rogers, J. (2013). Management of constipation in the community. Journal of Community Nursing, M27(2).

Sinclair, M. (2010). The use of abdominal massage to treat chronic constipation. Journal of Bodywork \& Movement Therapies, doi:10.1016/ j.jbmt.2010.07.007.

Sharma, K.S., Kaur, K., \& Garg, R. (2007). Factors affecting bowel movement in critically ill patients. Nursing and Midwifery Research Journal, 3(2), 71-78.

Supa'at, I., Zakaria, Z., Maskon, O., Aminuddin, A., \& Nordin, N.A.M.M. (2013). Effects of swedish massage therapy on blood pressure, heart rate, and inflamatory markers in hypertensive women. Evidence Based Complementary an Alternative Medicine, 2013, article id 171852,2-8.

Tekunduz, K.S., Gurol, A., Apay, S.E., \& Caner, I. (2014). Effect of abdomen massage for prevention of feeding intolerance in preterm infants. Italian Journal of Pediatrics, $40(1), 1-6$.

Uysal, N., Eser, I., \& Akpinar, H. (2012). The effect of abdominal massage on gastric residual volume. Society of Gastroenterologi Nurses and Associates, 35(2), 117-123.

Vincent, J.L., \& Preiser, J.C. (2015). Getting critical about constipation. Practical Gastroenterology. 144, 14-25.

Wiest, K., Asphaug, V.J., Carr, K.E., Gowen, E.A., \& Hartnett, T.T. (2015). Massage impact on pain in opioid- dependent patients in substance use treatment. International Journal Of Therapeutic Massage And Bodywork, 8(1), 13-24. 